\title{
Anmeldelse:
}

\section{Den glemsomme historie}

Af Jan Jakob S. Floryan

En af styrkerne ved Moorhouses bog er, at han grundigt gennemgår følgerne af Hitler-Stalin-pagten. Han har med denne bog gjort en stor og vellykket indsats for at placere Hitler-Stalin-pagten i centrum for Anden Verdenskrigs historie.

Moorhouse, Roger: En djævelsk alliance. Kristeligt Dagblads Forlag, 2015. 447 s.

Roger Moorhouse begynder med en beklagelse, man kun kan følge ham i: Hitler-Stalin-pagten er ukendt.

Den omtales ikke i historie-undervisningen selv på universiteterne i Storbritannien (og vel i Europa), og sker det, er det kursorisk. Moorehouse har bud på en forklaring, at bortset fra Polen og de baltiske stater "er det ikke en del af vores kollektive fortælling om Anden Verdenskrig". Pagten anses ikke for tilstrækkelig betydningsfuld til at blive fremhævet, og dog bør den det, fordi den er den direkte forudsætning for krigen.

Man kan udbygge Moorhouses forklaring - hvilket han i øvrigt er inde på længere inde i teksten - med den pro-sovjetsocialistiske skævhed, der synes indbygget i den vesteuropæiske akademiske klasses verdenssyn.

Pagtens indgåelse skabte kolossale vanskeligheder for Moskvas tro følgesvende

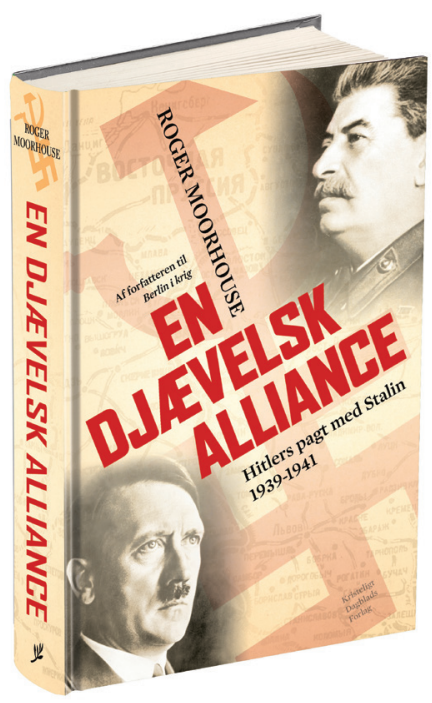

i Europa og USA, for hvordan forklare, at man nu skulle være allieret med nationalsocialisterne, som man hidtil havde bekæmpet som denne verdens afskum (hvilket var gensidigt). Det krævede en ideologisk drejning på $180^{\circ}$ og en betydelig dosis blind partidisciplin at gennemføre den. I Sovjetunionen gjaldt Stalins ord, og enhver muggen i rækkerne var livsfarlig.

I Vesten var Stalins morderiske hånd ikke helt så effektiv, men hans internationale partimæssige agentorganisation Komintern gjorde, hvad den kunne, for at få partierne til at makke ret. Et antal medlemmer trådte ud, men flertallet resolve-

Jan Jakob S. Floryan er cand.scient.pol. \& art.; fhv. korrespondent for DR i Moskva, Berlin m.fl. 
rede, at hvis Stalin beordrede det, måtte det tjene kommunismens sag bedst.

I det nationalsocialistiske Tyskland var reaktionen også forbløffelse og rådvildhed, men totalitære systemer besidder den nyttige evne til at gennemtvinge politiske volter og præsentere dem som successer. Det gjaldt den brede offentlighed, som man stillede de enorme sovjetiske råvarereserver i udsigt, og dem havde tysk industri i høj grad brug for, idet man forudså en britisk søblokade af Tyskland i tilfælde af krig, hvilket da også fandt sted.

Dertil kom, at der i Auswärtiges Amt i Wilhelmstrasse var en kreds af 'østvenner', der arbejdede for at udbygge det økonomiske forhold til Sovjetunionen og lade det blive fulgt op af en politisk-militær alliance. Pagten stipulerede den ønskede økonomiske og politiske tilnærmelse og tog på sin vis tråden op fra Rappallotraktaten mellem den tyske Weimarrepublik og Sovjetrusland fra 1922, indgået i fortrolighed, alt imens Tyskland udadtil forhandlede med Vestmagterne i Locarno.

Fra sovjetisk side var det industrielle samarbejde lokkemaden i forhold til befolkningen, men også i realiteten. Sovjetisk industri var notorisk tilbagestående, uanset hvor mange femårsplaner der blev overopfyldt. Altså blev det olie, metaller og korn for maskiner og våben.

Sovjetsocialisterne i Vesten slugte grosso modo Stalins kovending i pagtens gyldighedstid fra august 1939 til juni 1941. Siden har den apologetiske sovjetiske fremstilling af pagten betonet, at man fra begyndelsen af kendte til Hitlers aggressive planer, men var nødt til at vinde tid for at forberede sit forsvar. Denne søforklaring åd de vestlige intellektuelle med kyshånd, idet den renvaskede sovjetsocialismen, der således kunne trives videre som ideal hos den 'progressive intelligentsia'. Danmark ingen undtagelse.

\section{Skjulte motiver}

Moorhouse dokumenterer imidlertid i sin fremstilling, at de sovjetiske motiver ikke var, som siden hævdet. Det økonomiske samarbejde var attraktivt, men der var også overordnede strategiske ambitioner. Ideen var at lade Tyskland slås med de vesteuropæiske demokratier og lade dem forbløde. En sådan europæisk storkrig ville føre til en international arbejderopstand, hvilket ville få de herskende klasser i Tyskland, Storbritannien og Frankrig til at slutte sig sammen om at slå den ned. I denne situation ville Sovjetunionen træde ind i kampen på arbejdernes side og sovjetsocialismen sejre i hele Europa.

Stalins udenrigsminister, skriver Moorhouse, udtalte sågar, at det afgørende slag mellem kommunismens og reaktionens styrker ville finde sted omkring Rhinen. Sejren ville naturnødvendigt tilfalde den internationale arbejderklasse.

Hitler-Stalin-pagten var en vigtig træedesten på denne vej. Den blev underskrevet den 25. august 1939 om eftermiddagen af rigsudenrigsminister Joachim von Ribbentrop og folkekommissær for udenrigsanliggender Vjatjeslav Molotov under Stalins benevolente blik.

\section{Morsom karakteristik}

I øvrigt er Moorhouses karakteristik af de to ministre sarkastisk og morsom. Ribbentrop var en champagnesælger, der giftede sig rigt og tillagde sig det adelige von. Han var hurtig til at stige på Hitlers vogn, endnu før udsigten til magtovertagelse begyndte at blive reel. Hans styrke lå $\mathrm{i}$ at kunne følge Hitler loyalt som en hofsnog. Han var desuden selvoptagen, elskede at høre sig selv tale og at føre sig frem i al Det Tredje Riges pragt. Over for repræsentanter for lande, han mente stod under Tysklands niveau, var han hoven og arrogant.

I den henseende delte han mange træk 


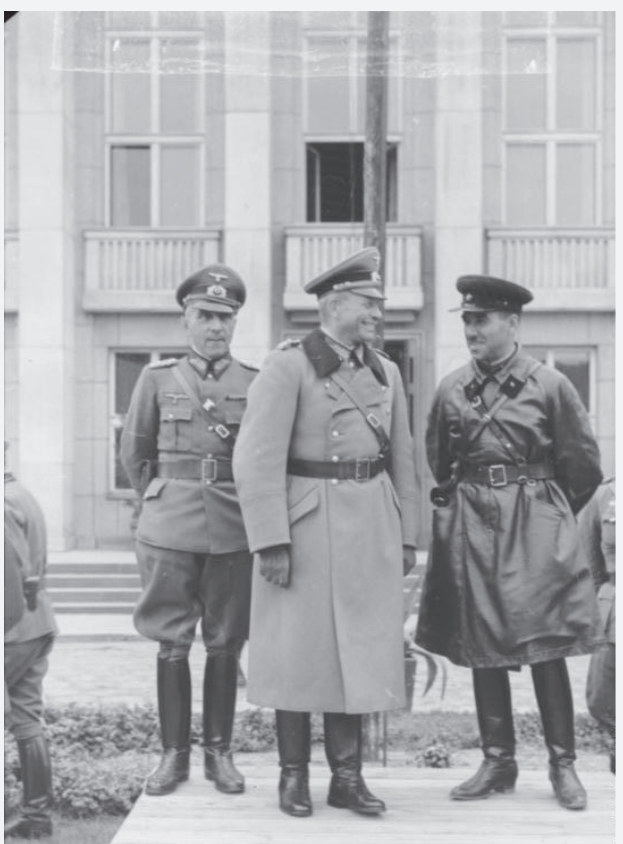

FOTO: Bundesarchiv via Wikimedia Commons
Generalerne Heinz Guderian [i midten] og Semjon Krivosjein [til højre] ved paraden i Brest. Forskellen i påklædning er slående: fra det elegante til det bondske. Guderian måtte finde sig i at stå ved siden af en jøde og dermed legemliggørelsen af den judeo-bolsjevisme, Hitler altid har tordnet imod. Omvendt skulle Krivosjein stå skulder ved skulder med repræsentanten for et regime, der som mål havde bekæmpelsen af den internationale jødedom. Jo, Hitler-Stalin-pagten var stærk kost. med Molotov. Han var også en overlever uden egne synspunkter eller bidrag, som ikke var sanktioneret oppefra. Hans slaviske loyalitet over for Stalin gik så langt, som til at deltage $\mathrm{i}$ herskerens natlige sammenkomster i datjaen uden for Moskva og danse med marskal Vorosjilov (der var ingen kvinder), mens hans egen hustru var sendt til Gulag. Han turde ikke over for Stalin, som han så dagligt, tage hendes sag op. Han risikerede at skulle følge samme vej.

Det positive, der blev sagt om Molotov, var øgenavnet 'kammerat stenrøv', fordi ingen kunne som han blive ved og ved med at sidde til møder og foranstaltninger, om de så varede fra klokken otte til klokken otte næste dag. Som Stalins var hans efternavn et revolutionært pseudonym afledt af hammer. Stalin var afledt af stål.

Ribbentrop og Molotov var således ikke selvstændige aktører i forhandlingerne. De fulgte nøje instrukserne fra deres her- rer og handlede kun inden for de afstukne rammer. Moorhouse viser klart og tydeligt, hvordan Hitler og Stalin åndede dem i nakken og pressede på for at få aftalen i stand. Mest Stalin, som Moorhouse udnævner til at være krumtappen i processen.

\section{Østeuropas skæbne}

Det særlige ved Hitler-Stalin-pagten underskrevet i Moskva var dens hemmelige tillægsprotokol. Her blev skæbnen for omtrent 50 millioner mennesker i Øst- og Mellemeuropa afgjort i fire punkter på en halv A4-side. Det var delingen af området, der gjorde det muligt for Hitler at angribe Polen seks dage senere og for Stalin at gøre det samme 20 dage senere.

Det var Polens fjerde deling. Pagten tilkendte også Sovjetunionen Finland, Estland, Letland og Litauen samt Bessarabien, den østlige provins af Rumænien. Inden for denne afgrænsning mod øst fik Hitler frit slag og rygdækning til at handle mod vest. 
Samme dag, den 25. august 1939, blev en anden pagt undertegnet af den britiske udenrigsminister viscount Edward Halifax og den polske ambassadør grev Edmund Raczyński. Den havde otte punkter og kunne være på én A4side. Her påtog Storbritannien sig at stå Polen bi ved et tysk angreb. Det var en uforbeholden støtteerklæring, der førte til den britiske krigserklæring den 3. september, hvilket forvandlede den sovjet- og nationalsocialistiske krig mod Polen til en verdenskrig.

Pudsigt nok var begge aftaler så korte og dog så usigeligt prægnante, mens EU's hundredvis sider lange aftaler ikke just kan siges at skrive sig ind i verdenshistorien.

\section{Følgerne af Hitler-Stalin-pagten}

Det er en styrke i Moorehouses bog, at han grundigt og overskueligt gennemgår følgerne af Hitler-Stalin-pagten. De er delt op i den storpolitiske og indenrigske side. Storpolitisk betød pagten en nyopdeling af Europa mellem Berlin og Moskva og indeholdt klare elementer af Hitlers senere Neuordnung. Den skabte desuden en økonomisk forbindelse mellem de to magter af stor betydning for udviklingen af deres krigspotentiale. Indenrigs førte pagten til fordrivelse, undertrykkelse, tortur og mord.

Tyskerne gik straks i gang med at omforme det slagne polske folk til en underklasse af slavearbejdere. Ti tusinder navnlig intellektuelle - blev sendt til koncentrationslejrene for aldrig at komme tilbage. Jøderne fulgte efter et par år senere. En tysk forvaltning blev gennemført og et apartheid-samfund oprettet i Generalgouver-nementet, der var den resterende del af Polen, efter at landets vestlige provinser var blevet inkorporeret $\mathrm{i}$ das Reich, mens de østlige var tilfaldet Sovjetunionen.
Hvor nationalsocialisterne koncentrerede sig om race, gik sovjetsocialisterne efter klasse. De besiddende klasser - helt ned til bønder, der havde mere end én ko - skulle undertrykkes. Videre skulle alle parasitære elementer elimineres. Det gjaldt navnlig 'de hvide hænder', dvs. mennesker, der ikke havde hårdt fysisk arbejde.

Omkring 400.000 polakker blev sendt til Kazakhstan og andre områder ubeboelige for mennesker fra civiliserede kår. Polakkerne blev regnet for upålidelige og stærkt påvirkede af det kapitalistiske samfundssystem. Dertil kom, at Rusland i 180 år havde hersket over det østlige Polen (til og med Warszawa), og russerne var passende forhadt blandt polakkerne. Som nationer brød de to største slaviske folk sig sandelig ikke om hinanden.

Såvel i det national- som i det sovjetsocialistisk besatte Polen (samt Baltikum og Bessarabien) gik en gigantisk demografisk reorganisering i gang. Under brutale, umenneskelige og dødbringende forhold.

Både den national- og den sovjetsocialistiske del af Polen samt de baltiske lande og Bessarabien blev omgående spændt for de to regimers krigsøkonomi. For Tyskland var det vigtigt at udnytte de polske områder til produktion af korn, som Riget fattedes, mens Sovjetunionen med den østlige del af Polen fik fat i industri, som var af mellemeuropæisk standard og derfor den sovjetiske overlegen.

\section{Slående forskelle}

Samarbejdet mellem de to magter, der nu var blevet naboer, foregik rimelig godt omend ikke gnidningsfrit. Man kan sige, at det begyndte allerede i den polske by Brest, der blev grænsebyen, og hvor de to forbrødrede hære holdt en parade. Forskellene var slående. For det første i materiel og anden udrustning, men også uniformering. 
Tyskerne var ligefrem elegante og selv de menige havde bælter og støvler af læder. Russerne havde bælter af stof og støvlerne havde kun en slags gamacher af læder, mens resten var tykt stof. De tyske læderremme til geværerne var hos sovjetsoldaterne ofte snore. Desuden præsterede tyskerne at ledsage paraden med en overflyvning af deres nyeste jagere, Messerschmidt 109, mens den sovjetiske general Krivosjein måtte nøjes med at sige til sin tyske kollega Guderian (der var hjernen bag den panserdrevne Blitzkrieg): "vi har nogen er der bedre".

Da den økonomiske udveksling kom i gang trillede godstog efter godstog over grænsen, omend der var vanskeligheder. De tekniske bestod i den forskellige sporvidde, der gjorde omladning eller udskiftning af bogier nødvendig. En anden hindring var det underudviklede jernbanenet $\mathrm{i}$ den vestlige del af Sovjetunionen.

Dertil kom en betydelig gensidig mistænksomhed, der førte til, at man ventede med at sende sine produkter af sted, indtil den anden parts leverancer var kommet frem. En sådan holdning fik jævnligt handelen til at gå i stå, hvilket krævede ordrer fra allerhøjeste sted for at sætte gang i den igen. Og ordrerne kom, fordi både Hitler og Stalin var besluttet på, at pagten skulle virke.

Et højdepunkt var Molotovs besøg i Berlin den 12. november 1940, hvor de praktiske trakasserier skulle afklares. Hans møde med Ribbentrop var ikke produktivt, fordi han gemte argumenterne og indrømmelserne til Hitler, som han traf dagen efter. Nu havde begge udenrigsministrene mødt hinandens herrer; et møde mellem Hitler og Stalin fandt aldrig sted.

Begge herskerne gjorde indtryk på deres samtalepartnere. Stalin med sin pibe og sit uudgrundelige smil; Hitler med sit intense, gennemborende blik.

\section{Operation Barbarossa}

Med visse tvistigheder fungerede pagten frem til Operation Barbarossa den 22. juni 1941, da omkring tre millioner tyske soldater angreb Sovjetunionen. Længe før det rådede de sovjetiske efterretningstjenester over data vedrørende en kolossal tysk styrkeopbygning langs grænsen. Dertil kom en række rapporter fra sovjetiske agenter.

Det blev alt sammen på det bestemteste affærdiget af Stalin, der alene så det som forsøg på at ødelægge det gode samarbejde med Tyskland. I Moskva herskede den fuldkomne fornægtelse af alle tegn på forestående tysk invasion, og Stalin hæftede sig ved, at der fra tysk side forelå intet krav, intet ultimatum. Da angrebet fandt sted, forbød han de sovjetiske styrker at besvare det offensivt.

De mange detaljer og det omfattende kildemateriale behandles suverænt af Moorhouse både fagligt og sprogligt. Hans bog rangerer ganske på linje med en anden britisk historiker Timothy Snyders Bloodlands. Europa mellem Hitler og Stalin, udgivet af JP Forlag i 2011 og anmeldt samme år af undertegnede $i$ Udenrigs. Begge forfatterne kredser om det vanskelige spørgsmål, hvordan kunne de to regimer finde frem mod hinanden. Den simple forklaring er, at de besad samme ideologi blot forskelligt forklædt. Nationalsocialismen havde udpræget socialistiske træk, men sovjetsocialismen havde nationalismen som en grundpille.

Påpegningen af lighederne var længe forbudt. I Sovjetunionen af klare magtpolitiske årsager og i Vesten, fordi 'den progressive intelligentsia' ikke ville acceptere den. Nu hvor marxismen-leninismen har sluppet sit kvælertag om den akademiske debat, kan Moorhouse fremsætte det dialektiske synspunkt, at hvis sovjetsocialismen var tesen, var nationalismen antitesen. 
Dette synspunkt førte allerede i slutningen af 1980'erne til den voldsomme historikerstrid i Vesttyskland. Her fremsatte Ernst Nolte den uhyrlige påstand, at Hitler blot var en reaktion på bolsjevismen. Det er den, der nu ligger til grund for Moorhouses betragtning. Dog nævnes Nolte ikke i litteraturlisten.

Moorehouse fremtræeder i lighed med Snyder som den rene historiker, og hans bog skæmmes ikke af lange teoretiske udledninger, som tyske og dermed danske historikere stadig præget af visse marxistiske tankekonstruktioner forfalder til. Her går man til sagen, fremstiller fakta og analyserer dem uden søgte forsøg på at sætte historien på formler.
Den djoevelske alliance er i lighed med Bloodlands oversat af den kompetente Peter Dürrfelt til et sikkert og letlæseligt dansk. Skal man anke over noget, er det, at han $\mathrm{i}$ begge bøger taler om en flod Vistula. Det er den engelske betegnelse for floden, som tidligere på dansk kaldtes ved det tyske navn Weichel og nu normalt omtales som det polske Wisła. Hvorfor denne Vistula, er uklart.

Med bogen har Moorhouse gjort en stor og vellykket indsats for at placere Hitler-Stalin-pagten i centrum for Anden Verdenskrigs historie. 